\title{
THE ALABAMA DDT SETTLEMENT FUND
}

\author{
Francis E. McGovern*
}

I

INTRODUCTION

The process of designing a claims resolution facility for dispensing settlement funds in a mass tort case is a microcosm of the process for creating societal compensation systems. The designer typically seeks to balance the competing interests of the various affected constituencies-courts, plaintiffs, defendants, counsel-consistent with larger community values of equity and efficiency. Because the claims resolution facility is usually constructed in the context of a consensual resolution of mass tort litigation, it becomes a compromise resolution with all the pitfalls associated with design by consensus. Unlike the more structured decisionmaking process in a representative democracy, however, each claims resolution facility is created through a less structured, ad hoc decisionmaking process. The lack of defined institutional safeguards, the strong potential for agency failure, unequal bargaining power, the nebulous and conflicting interests of the affected parties-all of which are inherent in cases involving mass numbers of plaintiffs - contain the seeds of an unbalanced claims resolution facility design that could thwart the intended best intent.

The following account of the creation of the allocation and distribution system in the Alabama DDT cases illustrates the tensions involved in designing a claims resolution facility. It is the history of successes and failures in these implemented facilities that holds the potential for establishing safeguards for the institution of new facilities. The information garnered from anecdotal and empirical reviews of existing facilities can provide factual constraints on the excesses of future designers and lead to a general acceptance of claims resolution facility models.

\section{II}

\section{History OF THE DDT Litigation ${ }^{1}$}

Approximately 1,200 residents of Triana, Alabama, filed suit against the Olin Corporation in 1979, alleging personal injury and property damage due

\footnotetext{
Copyright (C) 1990 by Law and Contemporary Problems

* Francis H. Hare Professor, University of Alabama School of Law. Also the special master who wrote the DDT allocation and distribution plan discussed in this article.

1. For a more complete discussion of the evolution of the litigation, see Francis E. McGovern, The Discovery Survey, 51 L \& Contemp Probs 41, 43-49 (Autumn 1988).
} 
to exposure to dichloro-diphenyl-trichloro-ethane ("DDT"). ${ }^{2}$ The plaintiffs contended that approximately 400 tons of the DDT produced by a pesticide plant owned by the Olin Corporation had escaped into a stream that fed into the Tennessee River, where it settled to the bottom and was ingested by bottom-feeding catfish. ${ }^{3}$

In 1981, the parties settled the lawsuit before trial in an agreement that provided for a $\$ 10,000$ payment to each plaintiff, the establishment of a health facility for all of the plaintiffs, and cleanup of the site over a five-year period. ${ }^{4}$ The settlement agreement was limited, however, to the original, named plaintiffs. ${ }^{5}$

New lawsuits were filed within several months after the settlement. From January to December 1983, approximately 10,000 additional residents from the area surrounding Triana filed suit in the United States District Court for the Northern District of Alabama against the Olin Corporation, the Tennessee Valley Authority, and the U.S. Department of the Army. ${ }^{6}$ Like the plaintiffs in the first lawsuit, these plaintiffs alleged personal injury, property damage, and economic loss from DDT exposure. After consolidating the actions, U. S. District Judge U. W. Clemmon appointed a special master to develop and oversee pretrial discovery. ${ }^{7}$

The parties and the special master then designed a discovery plan that was implemented in May 1984. ${ }^{8}$ Under the plan, the case was divided into three separate pretrial tracks that would merge into a single trial process. The first track involved general discovery of all plaintiffs, during which they were required to attend a joint session at which neutrals hired by the special master completed a fifty-four page questionnaire on each plaintiff. The questionnaire, which was given in lieu of interrogatories or depositions, obtained standard information on background, demographies, DDT exposure, and personal and medical histories. The second track, which

2. Cloud v Olin Corp., CA-79L-5128-NE (ND Ala, filed July 9, 1979); Parcus, et al. v Olin Corp., CV 80-PT-5098-NE (ND Ala 1980); Freeman, et al. v Olin Corp., CV 79-PT-5178-NE (ND Ala 1979); Charest et al. v Olin Corp., CV 79-PT-517-NE (ND Ala 1979).

3. The DDT, which is fat soluble, concentrated in the fatty catfish, the staple of the Triana residents' diet.

4. Cloud, CA-79L-5128-NE.

5. Id. The U.S. Government and the State of Alabama also became involved in an environmental clean-up action. State of Alabama v Olin Corp., CA 79-PT-5179-NE (ND Ala 1979); United States $v$ Olin Corp., CV 80-PT-5300-NE (ND Ala 1980).

6. Two sets of attorneys filed the actions. Wilhoite v Olin Corp., CV-83-C-5021-NE (ND Ala, filed January 11, 1983); Hagood v Olin Corp., CV-83-C-5917-NE (ND Ala, filed December 30, 1983). The two actions were consolidated along with Wilhoite $v$ Tennessee Valley Auth., CV-83-C-5670-NE (ND Ala, filed September 20, 1983). The Hagood complaint named both Olin and the Tennessee Valley Authority ("TVA") as defendants. Eventually, each group filed additional complaints, which were also consolidated. Hargett v Olin Corp., CV-85-HM-5078-NE (ND Ala, fled January 30, 1985); Washington v Olin Corp., CV-85-C-5127-NE (ND Ala, filed February 13, 1985); Washington $v$ Tennessee Valley Auth., CV-85-C-5127-NE (ND Ala, filed February 13, 1985); Ezell, et al. v Olin Corp., CV-86-HM5125-NE (ND Ala 1986); Hill, et al. v Olin Corp., CV-85-C-5510-NE (ND Ala 1985).

7. The author of this paper was appointed special master. Order Appointing Special Master, Wilhoite v Olin Corp., CV-83-C-5021-NE (ND Ala, filed August 10, 1983).

8. See McGovern, 51 L \& Contemp Probs at 43-49 (cited in note 1) (discussing the development and implementation of the case management plan). 
involved traditional in-depth discovery of twenty randomly selected plaintiffs, served to tease out the specific facts and the type of expert testimony to be expected in the eventual trial. The third track was reserved for legal issues to be resolved before trial-for example, motions to dismiss, motions for summary judgment, and motions in limine.

In May 1986, approximately one month before trial, the parties agreed to a $\$ 15,000,000$ settlement to be paid over two years. ${ }^{9}$ Olin preferred to settle the class action voluntarily as long as there was no large number of plaintiffs who did not accept membership in the class. The settlement was organized under Rule 23(b)(3) of the Federal Rules of Civil Procedure as an opt-out class action settlement and applied to all persons (1) who were present or former residents of six Northern Alabama counties around Triana since the Olin plant opened and who drank water or ate fish or animals containing DDT discharged as a result of the manufacture of DDT by Olin or who otherwise came into contact with Olin DDT and who claimed physical injury; or (2) who claimed any other injury or damage-economic or physical-related to the DDT discharge. ${ }^{10}$

In accordance with normal class notification procedures, notice was provided in both print and electronic media concerning the settlement to allow existing plaintiffs to opt out and new plaintiffs to opt in. ${ }^{11}$ Of the 10,119 plaintiffs who filed suit, 6,731 completed the necessary questionnaire and remained in the case. By October 15, 1986 three members of this group opted out of the class, but some 6,000 plaintiffs-including some 289 who had previously been dismissed for failure to complete the questionnaire-opted in, resulting in a total settlement class of more than $13,000 .^{12}$

Under the settlement agreement, the $\$ 15,000,000$ was placed in a fund and utilized to pay attorneys' fees set by the court, compensation for all class members, and administrative costs of the compensation procedure. ${ }^{13}$ The court appointed an administrator to (1) manage the assets in the fund; (2) distribute monies from the fund; (3) determine the accuracy of the distribution process; and (4) consult with the affected parties concerning these duties. The court also appointed a guardian ad litem to represent the interests of the minor plaintiff members of the class. The special master's responsibilities included (1) overseeing a process for collecting blood samples and current data from each of the plaintiffs; (2) designing a plan for allocating and distributing monies from the fund; (3) obtaining a consensus among the plaintiffs' attorneys, the administrator, and the guardian ad litem concerning that plan, and (4) deciding individual plaintiffs' appeals from the

9. Agreement dated June 2, 1986, Appendix to Order with Respect to Notice, Hearing, Class Certification and Administration of Class Action Settlement, In re Redstone Arsenal DDT Litigation, CV. 86-C-5313-NE (ND Ala June 2, 1986) ("Settlement Order").

10. The class also included the children of the persons in either of the categories.

11. Id; see also Fed R Civil Proc 23(b)(3).

12. Order Approving Allocation and Distribution Plan, In Re Redstone Arsenal DDT Litigation, CV86-C-5313-NE (ND Ala December 7, 1988).

13. Settlement Order at 13 (cited in note 9). 
administrator's distribution decisions. The court's role included (1) allocating attorneys' fees; (2) approving an allocation and distribution plan; and (3) hearing appeals from the special master and other parties, such as the administrator.

The settlement agreement further specified that funds could be dispersed only to plaintiffs (1) who were members of the settlement class; (2) who had a high blood level of DDT; (3) who manifested certain illnesses; (4) who resided in proximity to the Redstone Arsenal; and (5) who sustained losses related to Olin DDT. The fund paid for the requisite blood serum tests for the 7,051 plaintiffs who were in the class at the time of the settlement, but new plaintiffs (opt-ins) paid for their tests. The settlement agreement specified that neither the Olin Corporation nor its counsel were to be involved in the management, allocation, or disbursement of settlement funds.

At a fairness hearing on October 29, 1986, Judge Clemmon approved the settlement agreement and the appointments of the administrator and the special master. ${ }^{14}$ The special master then hired a team of public health experts $^{15}$ to design and implement a process for collecting blood samples and current information from each plaintiff, testing the samples for DDT, and organizing the new data for ease of processing. The special master also prepared a four-page questionnaire to facilitate the collection of data from the plaintiffs. ${ }^{16}$ The questionnaire was designed to determine (1) whether the plaintiffs had lived in the six counties during the relevant time period; (2) whether they alleged exposure to Olin DDT and, if so, how; (3) whether they claimed past, present, or future harm related to DDT and whether a doctor confirmed and treated the alleged harm; and (4) whether there was any additional information they would like to present. A social scientist also designed a survey to be given to a sample of the plaintiffs to determine their satisfaction (or lack thereof) with the various pretrial discovery procedures being utilized, and to elicit their opinions concerning how the monies in the fund should be dispensed. ${ }^{17}$ The survey compared the sample plaintiffs' reactions to the use of depositions, interrogatories, and the four-page questionnaire, in terms of, for example, understanding, assistance, treatment, and ability to present necessary information. The sample plaintiffs were also asked to rank a series of possible allocation and distribution options, and the level of expectations in the event of a cash award.

The blood sample and data collection process began in June 1987. Each week for a period of six months, approximately 500 plaintiffs received notice to attend a weekend blood and data collection session. Plaintiffs who lived more than 100 miles from Triana were given a blood sample and

14. Final Judgment and Order Approving Settlement, Hagood, et al. v Olin Corp., CV-86-C-5313. NE (ND Ala November 17, 1986).

15. The experts were from the School of Public Health at the University of Alabama at Birmingham.

16. For a detailed description of the questionnaire, see generally McGovern, 51 L \& Contemp Probs 41 (cited in note 1).

17. Professor E. Allan Lind designed the satisfaction survey, which is reported in id at 66-72. 
questionnaire kit that could be completed in their own communities. ${ }^{18} \mathrm{~A}$ second blood testing organization was hired to ensure that the analyses were properly calibrated. ${ }^{19}$

Of the 7,051 original plaintiffs whose cases were still active when the later, consolidated case was settled, 6,208 had their blood samples taken and completed an updated questionnaire. Of the 6,018 opt-in plaintiffs, 3,203 followed the same procedure-for a total of 9,415 settlement class members who were qualified to receive compensation from the settlement fund. ${ }^{20}$

\section{III}

\section{Allocation and Distribution of Settlement Funds}

\section{A. The Deliberative Process}

As the blood and data collection process proceeded, the special master, administrator, guardian ad litem, and class counsel began considering allocation and distribution systems. Although the settlement agreement had somewhat limited the method of dispensing funds, it allowed substantial discretion in deciding the precise criteria for distribution. The special master decided to operate in a consensus model, seeking agreement from the administrator, guardian ad litem, and class counsel before making any recommendations to the court. One obvious approach was to adopt the distribution system used in the previous case: assigning a flat value to each claim. This was rejected, however, because of the restraints on DDT exposure contained in the settlement agreement, the limited size of the fund in comparison to the number of claimants, and perceived disparities among the plaintiffs' DDT exposure and blood serum levels. Most of the members of the consensus group felt that the majority of the plaintiffs had little, if any, exposure to Olin DDT; thus there would be substantial inequity in treating the plaintiffs equally.

Another proposed approach involved a derivation of the social security compensation model: basing payment amounts in a small number of defined categories on severity of disability and need. This was rejected also, however, as it was deemed inconsistent with the settlement agreement provisions related to DDT exposure and inequitable because of the perceived disparities among the plaintiffs. From a tort perspective, the consensus group did not believe that there was even remote parity in the respective cases of the plaintiff group. The plaintiffs' lawyers were particularly concerned that an allocation model based upon "need" rather than "merit" would provide an unwanted precedent for a competing compensation system. ${ }^{21}$ There was also

18. Attendance at the weekend sessions for opt-in plaintiffs cost $\$ 63.00$; the kit cost $\$ 78.00$.

19. Administrative Practice and Procedural Manual for the Administration and Allocation of the Consent Settlement Fund, compiled by J. Mason Davis, Administrator, Robin E. Hopper, Legal Assistant, 1990 ("Practice and Procedural Manual").

20. Data drawn from the various Appendices to id.

21. The phenomenon is not unique to DDT. In the asbestos and A.H. Robins bankruptcies, plaintiffs' counsel tend to favor a tort-oriented approach. For an analysis of the various approaches 
substantial doubt that there was "merit" to any of the cases. The litigation risk was quite high that a court or jury would not have found proximate cause between the DDT exposure and the alleged harms. Although the defendant ${ }^{22}$ had agreed to a financial payment in connection with settlement, its rationale was based upon the practical realities of a potential jury verdict in the county where the bulk of the plaintiffs lived rather than upon the validity of the complaint. The consensus group decided, however, to accept the possible fiction that the cases had merit and use that fiction as the basis of an allocation system. The group viewed the acceptance of the litigation blackmail theory of recovery with its attendant corollary that all of the plaintiffs were equally unimpaired by exposure to DDT as being an unsavory foundation for an allocation system.

An alternative suggestion was to establish a medical facility for the plaintiffs so that they could receive free diagnostic medical care and at least some medical treatment. Although the settlement of the original case had contemplated such an arrangement in addition to cash payments, the medical facility had never been established because the plaintiffs had preferred additional cash payments instead. The consensus group members, although preferring some type of facility themselves, deferred to the earlier experience in designing their allocation system and decided against the establishment of a medical facility.

A fourth approach suggested by the public health experts involved a series of filters and a point system to assign values. ${ }^{23}$ Although the experts were unable to find any statistically significant correlations among the relevant variables-(1) claimed past injury; (2) claimed present injury; (3) claimed future injury; (4) status as a plaintiff; (5) level of DDT in blood serum; (6) distance of residence from plant site; (7) length of residence in area; (8) age; (9) sex; and (10) race 24 - a generally accepted epidemiological study, known as the Hanes II study, provided them with solid information on expected levels of DDT in individuals living in the South. ${ }^{25}$ The study suggested that there were statistically significant differences among persons of different age, sex, and race, but that other variations in DDT levels could not be explained by any other collected variables. The public health experts suggested that the known standard of DDT blood levels be used as a first level filter to screen out

taken by claims resolution facilities, see Mark A. Peterson, Giving Away Money: Comparative Comments on Claims Resolution Facilities, 53 L \& Contemp Probs 113 (Autumn 1990).

22. Although Olin, TVA, and the U.S. Army were all defendants initially. TVA and the Army filed motions to dismiss, which were granted. Thus Olin was the sole defendant at this point.

23. Personal communication with William F. Bridgers, February 22, 1988 ("Bridgers Communication"). When DDT enters the body, it is metabolized into DDE, which is detectable in the blood. The DDT blood test therefore actually analyzes the blood serum for the presence of the DDE metabolite, which acts as an acceptable surrogate for DDT level. All future references to the DDT blood test refer to the blood serum DDE test.

24. There appeared to be some relationship between DDT level and employment at Olin, but the correlation did not apply to other family members.

25. The Hanes Study, which collects and collates data on a random sample of individuals, is conducted periodically by the federal government. The collected data is stored on tape and is available to investigators. The survey used in the calculations here was conducted in 1987. 
those persons who should not receive compensation. For the individuals with elevated blood serum levels, two other filters were suggested: (1) a claim of exposure to Olin DDT and (2) residence in the six-county area near Triana. For plaintiffs who passed through these filters, the experts devised a point system based upon the level of DDT above background, three levels of claimed harm (low, moderate, severe), the duration of past claimed harm and present claimed harm, existence of future claimed harm, and life expectancy.

Although elegant in its design and equitable in application, there was no consensus to support the filter system. Aside from the filters, there was no authority to support the selection of categories for which points would be assigned or the designation of points among those categories. Once the decision was made to discriminate among plaintiffs, there was a strong desire to do so on a rational basis and not solely by the application of the value system of the special master, administrator, guardian ad litem, and class counsel. In particular, the consensus group was insistent upon a system of dispensing funds that utilized the same criteria as the system that provided the funds in the first place-the tort compensation system. Under this view, several aspects of the filter system were acceptable. First, its reliance upon a background risk filter was consistent with the tort compensation system; certainly plaintiffs who did not have an above-normal level of DDT would not be compensated in the tort system. Similarly, the filter related to exposure to Olin DDT-claimed exposure and residence in the relevant area and during the appropriate time frame-was a reasonable element of a plaintiffs' case in a tort action. The point system, however, had no analogy in tort law. The consensus group instead identified certain harms that had been suggested by plaintiffs' medical experts as being related to DDT. In a sense, then, these harms had been raised as fact issues, although not adjudicated as such. Thus, if a person could prove an injury that was identical to the harms identified by the plaintiffs' own experts, then the person could qualify for compensation.

Once a determination had been made of the precise types of harms that would trigger compensation, the issue of the amount of compensation remained. The tort system yardstick for compensation is jury verdicts. Thus the payment amounts were established with reference to typical jury verdicts and settlements for similar harms.

Conceptually, this approach had substantial attractiveness in mimicking the tort system. There were, however, two major problems: First, would a court allow recovery for risk of future harm because of an increased body burden of DDT without one of the enumerated specific harms? And, second, given the fact that the case arguably had been settled at a discount related to litigation risk, how should this be factored into the compensation plan? The practical implementation of the proposed allocation plan was also a problem. Of the approximately 13,000 members of the settlement class, about 3 percent had alleged the specific harms raised as fact issues whereas more than 
$33^{1 / 3}$ percent had levels of DDT higher than expected. ${ }^{26}$ This data suggested that the filtering process utilized by the plaintiffs' counsel to select their clients had been substantially more porous than in normal tort litigation, and that expectations of the bulk of the plaintiffs would be substantially unmet. To address these concerns, a "law of the case" was developed, allocating some monies for plaintiffs with only elevated DDT blood levels and some for those who had elevated DDT blood levels and had alleged at least one of the specified harms.

Minor plaintiffs and latent harms were two other major areas of concern. Unfortunately, the Hanes II study did not provide a solid yardstick for persons under sixteen years of age. Moreover, Alabama law mandated a cumbersome and expensive procedure for settling cases involving minors. Thus even minimal payments to minors would be exceeded by the related transaction costs. Finally, the pecuniary interests of the parents and children were not necessarily identical, and there was some skepticism whether parents would faithfully protect the interests of the minor once money had been dispersed. The consensus group was also concerned that payments to presently harmed plaintiffs would deprive plaintiffs with identical, but latent harms. Due to these related concerns, it was decided to defer the compensation of minors until they reached the age of majority and to establish an insurance fund to compensate for future harms.

B. The Preliminary Data

The data from the blood sampling process tended to confirm the assumptions of the consensus group. Of the 9,415 plaintiffs who gave a blood sample and completed the updated questionnaire, 9,281 alleged exposure to Olin DDT-7,033 adults and 2,248 minors. Of that number, 3,103, or approximately 33 percent, had blood levels of DDT that were above expected levels for the same age, sex and race-2,882 adults and 221 minors.

26. Practice and Procedural Manual at Appendices generally (cited in note 19). 


\section{Chart 1}

\section{Plaintiffs Above and Below Background Levels of DDT}

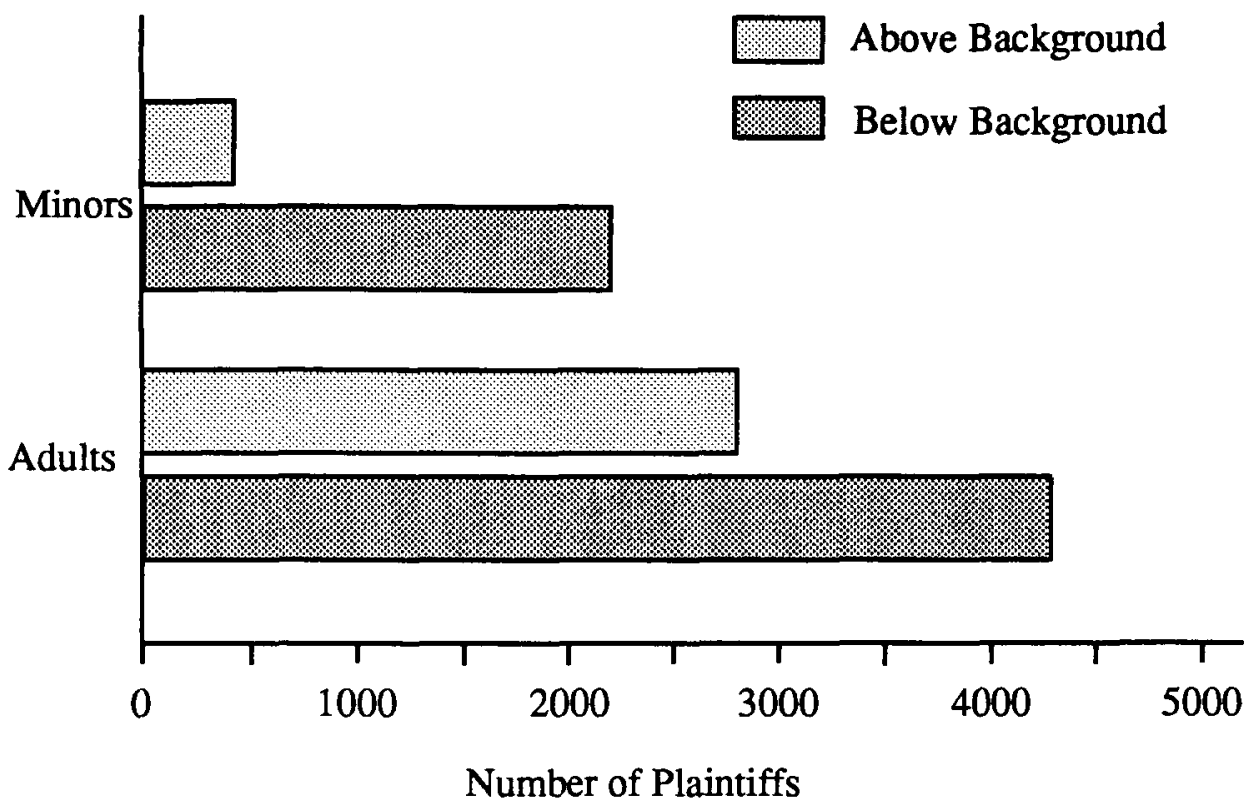

Interestingly, the bulk of the elevated DDT blood levels came from the plaintiffs who were originally in the suit, confirming the suspicion that the normal filtering role of plaintiffs' counsel had been virtually non-existent. 
Chart 2

\section{Comparison of Plaintiff Groups}

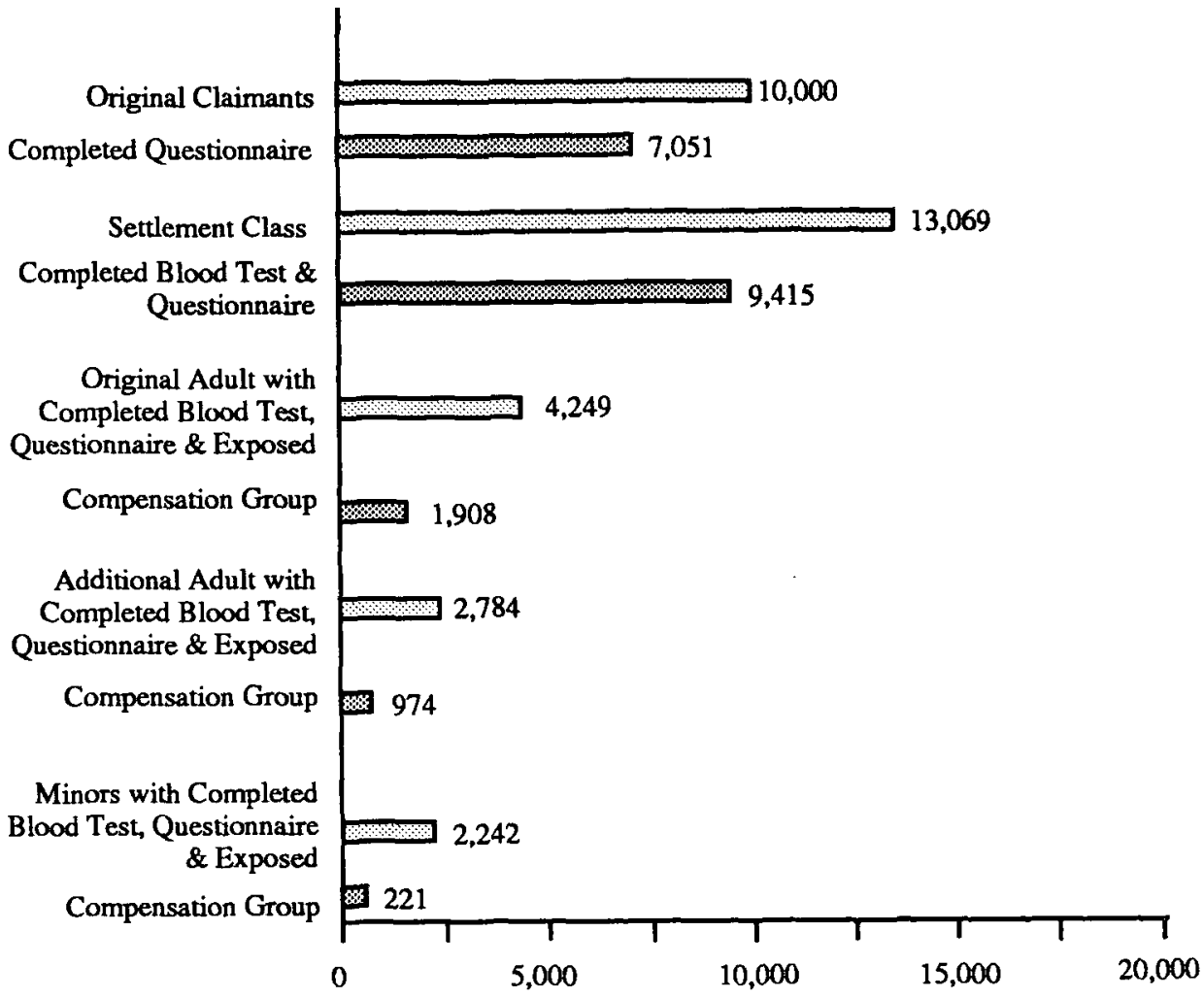

Number of Plaintiffs

Using a ratio scale, the plaintiffs were organized according to the number of multiples their blood levels exceeded the expected DDT levels. Two plaintiffs had a multiple of forty or above. Fifty-seven had multiples between ten and thirty; 220 had multiples between five and ten; 1,090 had multiples between two and five; and 1,750 had multiples above one but no higher than two. 


\section{Chart 3}

Plaintiffs Exceeding Background Levels of DDT

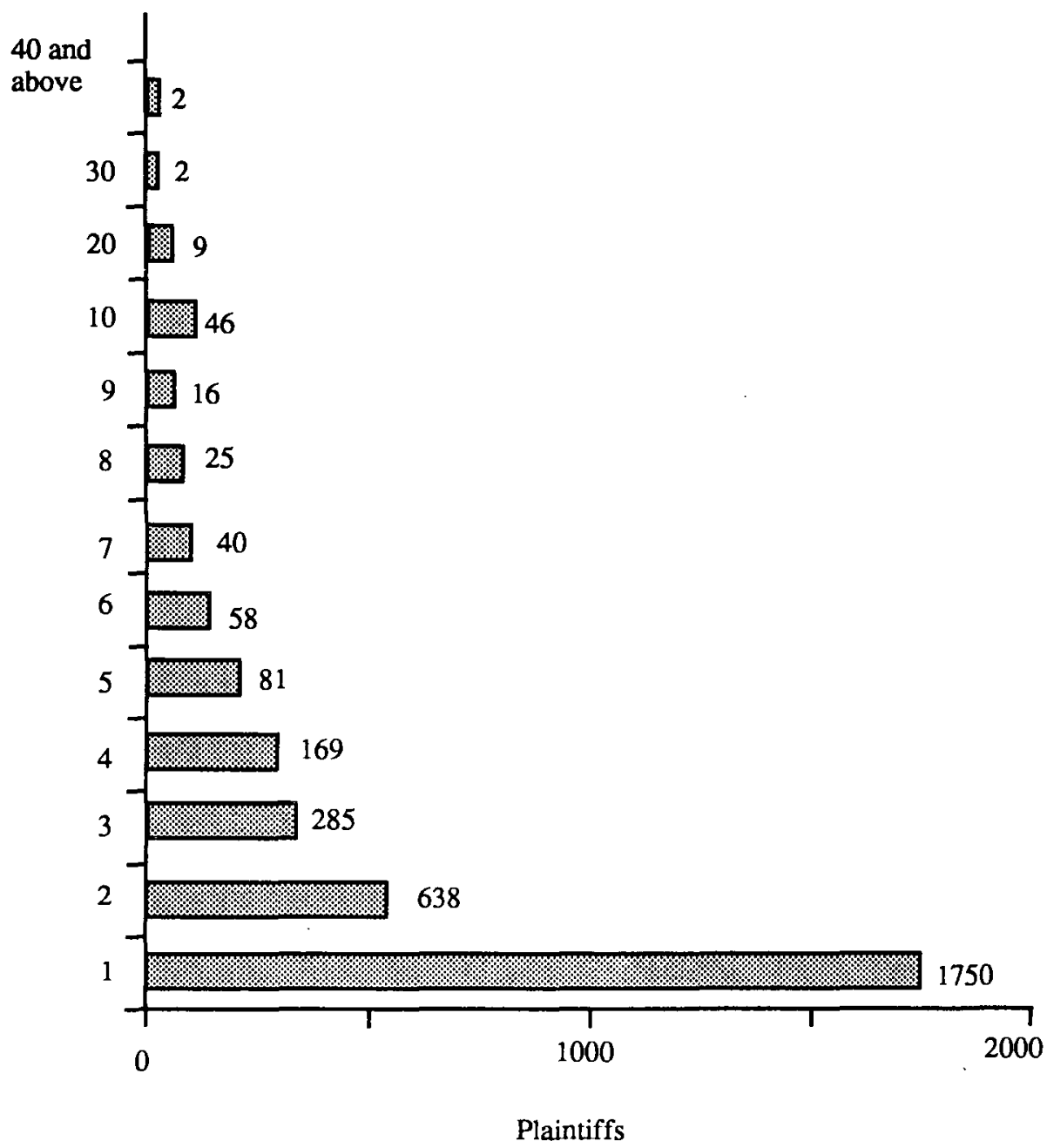

Approximately 150 plaintiffs alleged they had been diagnosed by a physician for past, identified harms, and 320 alleged present, identified harms. This method of self-reporting has its strengths and weaknesses. In the context of a fund to be dispersed to plaintiffs with physical harms, substantial overreporting would ordinarily be anticipated. Interestingly, the reporting of hypertension was actually lower than that which would have been expected from a control population from Northern Alabama. ${ }^{27}$

The interviews of 662 plaintiffs concerning their preferred outcomes for the litigation also tended to confirm the assumptions of the consensus

27. This can partially be accounted for by the low level of medical care in the region and the filter requirement of a medical diagnosis. Bridgers Communication (cited in note 23). 
group. ${ }^{28}$ All of the potential outcomes listed on the satisfaction survey received favorable responses: 72 percent approved of the medical report showing a normal DDT blood level; 76 percent approved of free medical tests for medical problems from DDT exposure; 81 percent approved of free medical insurance for DDT-related injuries; 76 percent approved of a free clinic; and 90 percent approved of a cash award. When asked which single outcome they preferred, 79 percent of the plaintiffs chose a cash award, 8 percent chose insurance, 8 percent chose a medical report, 2 percent chose a clinic, 2 percent chose medical tests, and 1 percent chose an open-ended, plaintiff-specified option.

As to the precise amount of a cash award, 36 percent were unable to provide any specific number. Many of those who did not give an amount responded that they should receive whatever everyone else received, but that they did not know what amount would be fair. The plaintiffs who did provide specific amounts gave answers ranging from $\$ 500$ to $\$ 5,000,000$. The modal response was $\$ 10,000$; the median response was $\$ 15,000$. To the extent that there were any expectations about the settlement amount, they appeared to be based upon the $\$ 10,000$ settlement value of the previous case. This uncertainty about what would be fair seemed to make the plaintiffs openminded about an allocation system, but the frequency with which plaintiffs responded "whatever everyone else gets" suggested that attention should be devoted to explaining why some plaintiffs were to receive more than others.

\section{The Ultimate Plan}

Based upon the consensus group's deliberations, the preliminary data, and necessary additional research, the special master wrote an allocation and distribution plan for the settlement fund. ${ }^{29}$ Judge Clemmon conducted a fairness hearing on the plan on November 21, 1988, in an overflowing courtroom with approximately 300 persons in attendance. The special master explained that the plan attempted to balance the sometimes conflicting goals of fairness, equality and efficiency by establishing a decision-tree model for the allocation of funds. ${ }^{30}$ To recover under the plan, a plaintiff needed to be a member of the settlement class, to provide a blood sample as a part of the official testing process, and to complete the updated questionnaire. (This information was easily verifiable from court records.) The plaintiff also had to have alleged exposure to DDT from the Olin facility at the Redstone Arsenal. Because there were no markers for Olin DDT - that is, it is indistinguishable from other DDT once in water-plaintiffs were assumed to have been exposed to it if they (1) alleged residence in the Triana area during the times when Olin DDT was prevalent, (2) alleged exposure to Olin DDT in a manner

28. Memorandum from $E$. Allan Lind on the results of the plaintiff interviews, June 30, 1988 (on file with author).

29. Proposed Allocation and Distribution System, attached to Order Approving Allocation and Distribution Plan, In re Redstone Arsenal DDT Litigation, A-86-C-5313-NE (ND Ala December 7, 1988).

30. For a more specific articulation of the goals, see id at 1-2. 
consistent with such exposure, and (3) had a level of DDT equal to or above expected levels. ${ }^{31}$

Individuals who met these criteria would receive $\$ 500$ for each rough multiple of actual DDT level above the expected level. ${ }^{32}$ For example, a plaintiff with a DDT level three times more than the normal, background level would receive $\$ 1,000$.

If a plaintiff alleged on the updated questionnaire a past or present injury that was one of the specified harms, ${ }^{33}$ and alleged that a physician confirmed the harm, and produced an affidavit from a physician confirming this fact, then that plaintiff would receive compensation based upon the following schedule:

(1) present specific harms ${ }^{34}$
(a) carcinogen
$\$ 10,000-\$ 60,000$
(b) reproductive
$\$ 10,000-\$ 30,000$
(c) hypertension
$\$ 7,500$
(d) mutagen
$\$ 10,000-\$ 60,000$
(e) central nervous system
$\$ 10,000-\$ 60,000$

(2) past specific harms ${ }^{35}$
(a) carcinogen
$\$ 5,000-\$ 30,000$
(b) reproductive
$\$ 5,000-\$ 15,000$
(c) hypertension
$\$ 3,750$
(d) mutagen
$\$ 5,000-\$ 30,000$
(e) central nervous system
$\$ 5,000-\$ 30,000$

If a plaintiff who met the first three criteria was deceased, and the autopsy, death certificate, or affidavit from a physician confirmed one of the specific harms, then compensation would be as follows:

31. Id at 2-6.

32. Id at 20.

33. The special master, in consultation with the class counsel, reviewed all the depositions of plaintiffs' medical experts to determine the alleged specific harms:

(1) carcinogenesis (cancer), including liver tumor, bronchogenic tumor, lung lymphoma, ovary carcinoma, follicular-cell carcinoma;

(2) reproductive harms, including infertility, intrauterine growth, retardation, premature labor, spontaneous abortion, "reproductive" problems;

(3) hypertension, including high blood pressure, high blood cholesterol, high triglycerides;

(4) mutagenesis, including mutagen, chromosome aberrations, cell transformation, deformity, Downs syndrome, hydrocephalus; and

(5) central nervous system harms, including learning disability, behavioral changes (increased errors, decrease in aggressiveness, low conditional avoidance response, extension of conditioned reflexes), tremors, convulsions, comas, retardation, epilepsy, cerebral palsy, and hyperactive.

Id at 16-17.

34. Id at 21 .

35. Id. 
(3) specific harms of deceased ${ }^{36}$
(a) carcinogen
(b) reproductive
(c) hypertension
(d) mutagen
(e) central nervous system

$\$ 5,000-\$ 30,000$
$\$ 5,000-\$ 30,000$
$\$ 5,000-\$ 30,000$
$\$ 5,000-\$ 30,000$
$\$ 5,000-\$ 30,000$

In all categories, the compensation was additive; that is, qualifying plaintiffs would receive compensation for both elevated levels of DDT and specific harms. Aside from the payment for DDT level, the precise amounts within each category were determined by the administrator on a case-by-case basis. ${ }^{37}$

Plaintiffs could also be compensated for economic loss from the interruption of a commercial fishing operation because of DDT from the Olin facility at the Redstone Arsenal, if they could establish such loss through tax returns, receipts, or similar documents. A special fund of $\$ 200,000$ was set aside for that purpose. ${ }^{38}$

Plaintiffs who had been deposed during the pretrial phase of the case would be compensated $\$ 500$ per deposition for time and expenses. These payments were also additive.

As noted above, minors were treated differently. Fifteen percent of the settlement funds were set aside for plaintiffs who were less than nineteen years old on December 15, 1988. Although minors represented almost 25 percent of the eligible plaintiffs, less than 10 percent of them-as opposed to approximately 40 percent of the adults-had elevated DDT blood levels. ${ }^{39}$ Minors who had elevated DDT blood levels and one of the specific harms were immediately compensated. Compensation for minors who had only elevated DDT blood levels was delayed until the minors reached the age of majority. If the minor plaintiffs had one of the specified harms at that time, they could qualify for additional compensation. At the age of majority, minors could obtain, at their own expense, a new blood test. If they had a higher than expected DDT level for their age, sex, and race, they would receive compensation. Each year the administrator would prorate the 15 percent fund in accordance with the number of minors. Any monies not

36. Id.

37. Jury verdicts and settlements in comparable cases in Alabama discounted for the litigation risk in the overall case constituted the yardstick for the values and relative values for the various harms to be compensated by the settlement fund.

38. The reserved amount was determined in a manner similar to the specific harm values. The fund was later elevated to $\$ 399,999.60$. December 15,1989 Order appended to Petition for Authorization to Disburse Consent Settlement Funds for Economic Loss and to Amend Allocation and Distribution Plan, In re Redstone Arsenal DDT Litigation, CV 86-C-5313-NE (ND Ala January 23, 1990).

39. Practice and Procedural Manual at Appendices generally (cited in note 19). This difference may be explained by a change in behavior in the early 1980 s caused by the posting of warning signs along the river by the Center for Disease Control. If residents refrained from-or strictly limited-the ingestion of fish from the river, the child population, which for the most part had not yet been exposed to the DDT, would necessarily have lower DDT blood levels. 
necessary to compensate the minors attaining the age of majority that year would automatically be transferred into the insurance fund described below.

Up to 10 percent of the available settlement funds was set aside in an insurance fund to be used to compensate for newly developed cancers, good cause exceptions, and unanticipated future events. Any plaintiff who otherwise qualified for compensation and who subsequently developed one of the specified cancers would receive additional compensation in accordance with the current specific harm payment schedule. The insurance fund would also be used to provide compensation to plaintiffs who did not meet the criteria for compensation but who met the criteria based upon a one time only DDT blood retest taken at their own expense. Persons who successfully appeal decisions of the administrator or those who will suffer from future harms that cannot currently be anticipated are other possible beneficiaries of the insurance fund. If the administrator found that the financial demands on the insurance fund in any given year would unduly deplete the fund, then the compensation payments would be prorated. If the administrator determined that the fund would contain excess monies for a given year, the issue would be referred to the court.

The distribution system involved a computerized list of plaintiffs, the results of the blood tests, the plaintiffs' answers to the questions relevant to the allocation decision rules, expected levels of DDT adjusted for age, sex, and race, and the decision rule in the allocation system. The administrator would spot check all the information provided by the plaintiffs, including the original questionnaire, to ensure accuracy. Once the administrator completed the data base, he would send the following information to each member of the settlement class:

(1) a brochure explaining the allocation and distribution process;

(2) the expected background level of DDT for each plaintiff adjusted for age, sex, and race;

(3) the actual DDT level for each plaintiff expressed in terms of its metabolite, DDE;

(4) an explanation of the relationship between actual and expected DDT levels as well as the ratio between the two;

(5) if applicable, a check to compensate for increased DDT level;

(6) if applicable, a form for a physician's affidavit to confirm a specific harm;

(7) if applicable, a form to verify economic loss; and

(8) if applicable, a check for deposition expenses.

Once a plaintiff provided sufficient verification to warrant compensation, the administrator would send the appropriate check. Endorsement of the check constituted a release and a waiver of the right to an additional DDT blood test. The costs associated with the administration of the settlement fund for any given year would not exceed the interest received from investing the unpaid balance of the settlement fund during that same year. Plaintiffs 
would have access to all information concerning their specific case, and an appeal would be available to the special master and the court.

The plaintiffs' comments at the fairness hearing held by Judge Clemmon were generally limited to oral statements of dismay at the size of the compensation amounts and the amount of the attorneys' fees; there were no substantive written comments. The news media coverage of the hearing focused on the relative size of the attorneys' fees to the settlement as a whole. After the hearing, Judge Clemmon approved the allocation and distribution system on December 7, 1988. On December 21, approximately $\$ 3,600,000$ was sent to the plaintiffs for increased levels of DDT, $\$ 3,500,000$ was allocated for anticipated claims of specific harms, $\$ 1,400,000$ was set aside for minor plaintiffs, and approximately $\$ 800,000$ was put into the insurance fund. ${ }^{40}$

\section{A Brief Critique}

On balance, the allocation and distribution plan has met the needs of its designers. Its implementation has been too slow and costly, however, and it has not been totally satisfactory to the members of the settlement class in terms of public relations. Because so few plaintiffs had any harms other than those that would normally be expected, and because very few plaintiffs had participated in either the settlement of the case or the design of the allocation and distribution plan, the public relations task was probably insurmountable. The alternative flat payment approach would have given each member of the settlement class less than $\$ 100$, an amount significantly less than the $\$ 10,000$ per plaintiff in the earlier case. The discrepancy would have created major dissatisfaction for those who felt they should receive a payment identical to payments received by previous plaintiffs. If each person with an elevated DDT level had received a flat amount, they would have received approximately $\$ 3,000$. This still would have been significantly less than the payment to the original plaintiffs. Thus the total amount of money deemed appropriate by counsel in evaluating the case could not have been allocated on a pro rata basis without creating a sense of unequal treatment between the previous and current plaintiffs. On the other hand, complaints among current plaintiffs concerning disparities in payment could have been substantially reduced by a pro rata allocation. If everyone had received the same amount, rather than a minority receiving larger amounts, there would have been a smaller number of potentially dissatisfied plaintiffs.

The appeals process has provided a helpful vehicle for venting concerns. Of the approximately 500 appeals, the vast majority have related to a general dissatisfaction concerning the overall settlement amount, the size of the attorneys' fees, misunderstandings of the allocation and distribution plan, and the continued presence of DDT near the Tennessee River. ${ }^{41}$ Although none

40. See various orders included as Exhibits to Practice and Procedural Manual (cited in note 19).

41. Occasionally, however, there were quite interesting issues raised. For example, one appeal raised the question whether a plaintiff who alleged injury in utero could be compensated where the 
of these concerns are specifically addressed by the appeals process, there seems to be some satisfaction on the part of the class members to have this vehicle for expressing their concerns. ${ }^{42}$ That is, the appealable issues were limited to tort compensation issues such as qualification for compensation and amount of compensation. The issues raised by the plaintiffs were more behavioral.

Probably the most troublesome concerns expressed by class members involve adjusting DDT levels for age, sex, and race and accounting for an inability of some plaintiffs to self-report. The HANES II study reflected the reality of life in the South-certain ages, sexes, and races had been disproportionately exposed to DDT. Persons who were active in cotton production prior to the banning of DDT, for example, were expected to have higher levels. By using this data for background levels, the allocation plan in effect compounded these prior inequalities. On the other hand, the function of the plan was not to rectify all previous wrongs but to take the world as it was found at the time of the lawsuit and allocate funds accordingly. The existence of so applicable a yardstick as the HANES II study was too attractive to ignore in the face of the public health experts' insistence on its validity.

Self-reporting-so prominently employed as an attempt to lower transaction costs-also produced fairly serious problems. The public health experts found the reporting of harms so inaccurate as to preclude any sound statistical correlations between exposure and harms. In individual cases, where, for example, a person neglected to list a personal injury that was truly valid, some class members, through their own error, were determined ineligible for compensation. It remains questionable, however, whether the additional expense necessary to cure these problems would have been worthwhile. The transaction costs would exceed the error costs in monetary and behavioral terms by the application of alternative value systems. As with most claims resolution facilities, the DDT system involved substantial tradeoffs that can be readily second-guessed by the application of alternative value systems. In the absence of more hard data to provide guidance, anecdotal decisionmaking prevails.

\section{IV}

\section{Conclusion}

In 1986 approximately 13,000 plaintiffs from Northern Alabama who alleged personal injuries and economic losses associated with exposure to DDT settled their cases with the Olin Corporation for $\$ 15,000,000$ in a Rule

plaintiff's mother had an elevated DDT blood level but the plaintiff did not. The answer is "yes" if there is competent medical evidence that the harm could have originated in utero. Order Affirming Opinion of Special Master, Hagood et al. $v$ Olin Corporation, CV 86-C-5313-NE (ND Ala January 23, 1990).

42. In one instance, an attorney collected several hundred clients who each paid a $\$ 100$ retainer to appeal the court's order approving the allocation and distribution plan after the time for appeal had expired. This instance not only suggested a level of dissatisfaction by certain class members but also nicely illustrates the opportunities for others to take advantage of that dissatisfaction. 
23(b)(3) settlement class. All the parties decided to establish a fund and a claims resolution facility to distribute monies from the fund. Counsel for plaintiffs, a guardian ad litem, the fund administrator, and a special master designed the claims resolution facility by consensus with input from the plaintiffs themselves and the approval of the court. The consensus group decided to balance various fairness, efficiency, and behavioral interests by mimicking the tort system to establish compensation values while substituting various administratively attractive standards for customary tort rules and procedures to reduce transaction cost. These surrogate decision rules were driven by objective factors-such as DDT blood levels, residence and exposure history, and medical records-which were obtained from the plaintiffs themselves. Once the court approved the overall allocation system, which included separate treatment of adults and minors and an insurance fund, the administrator applied the decision rules to individual cases and distributed the funds accordingly. This case suggests that it is feasible to retain traditional tort values consistent with greater efficiency by engrafting administrative procedures onto underlying litigation and creating a hybrid tort-administrative law process. 